\title{
Experimental study on the determination of average concentrations of polluting emissions for a thermoelectric power plant
}

\author{
Stela Dinescu ${ }^{1 *}$, and Claudius-Andrei Popescu ${ }^{2}$ \\ ${ }^{1}$ University of Petroșani, Department of Mechanical, Industrial and Transport Engineering, University \\ Street 20, Petroșani, România \\ ${ }^{2}$ Ministerul Afacerilor Interne - Poliția Română, România
}

\begin{abstract}
There is the problem of determining the polluted emissions in the case of a thermal power plant that uses coal as the main fuel in the Jiu Valley Mining Basin. The experimental determinations were performed at the points located behind the electrostatic precipitators and at the accessible points located behind the flue gas fans. These targeted mass flows and concentrations for indicators: $\mathrm{O}_{2}, \mathrm{CO}, \mathrm{CO}_{2}, \mathrm{NO}_{\mathrm{x}}, \mathrm{SO}_{2}$, dust: $\mathrm{PM}$ 10, PM 2.5, and total. The paper presents the values of average concentrations, determined experimentally, regarding pollutant emissions, including dust. The emissions for the analyzed energy groups were determined, for each category of polluting emissions comparative histograms were made.
\end{abstract}

\section{Introduction}

Coal based power plants in Romania are highly polluting through emissions of particles, Sulphur dioxide, nitrogen oxides, carbon dioxide and carbon monoxide.

As a European Union member and signatory of the UNECE13/CLRTAP14 convention, Romania publishes annual estimates of atmospheric pollutants under the 2001/81/CE directive [1] regarding national emission limits (which are implemented in the national legislation HG 283/2017 for updating HG 1856/2005 with regard to the national emission limits of certain atmospheric pollutants) and according to the protocols of the above conventions.

The member states must observe emission limits agreed in the Gothenburg Protocol through adopting the necessary measures to reduce the impact of anthropic activities upon the environment. Romania must reduce its annual emissions of gases that produce greenhouse and eutrophication effects and impact the ozone layer under $918 \mathrm{kt}$ for Sulphur dioxide $\left(\mathrm{SO}_{2}\right), 437 \mathrm{kt}$ of nitrous oxides $\left(\mathrm{NO}_{\mathrm{x}}\right), 523 \mathrm{kt}$ volatile organic compounds (NMVOC) and $210 \mathrm{kt}$ of ammonia $\left(\mathrm{NH}_{3}\right)$.

The main objective of this paper is to determine the emissions of pollutants from a power station that uses coal with an average calorific capacity of $15392 \mathrm{~kJ} / \mathrm{kg}$ from the Jiu Valley Basin.

\footnotetext{
*Corresponding author: dinescustela@yahoo.com
} 
The experimental measurements include concentrations for the following indicators: $\mathrm{O}_{2}$, $\mathrm{CO}, \mathrm{CO}_{2}, \mathrm{NOx}, \mathrm{SO}_{2}$, and particulates such as: PM 10, PM 2,5 as well as total emissions.

\section{Selection of strategic sampling locations}

The sampling locations for the key sources of environmental pollutants are presented in Figure 1.

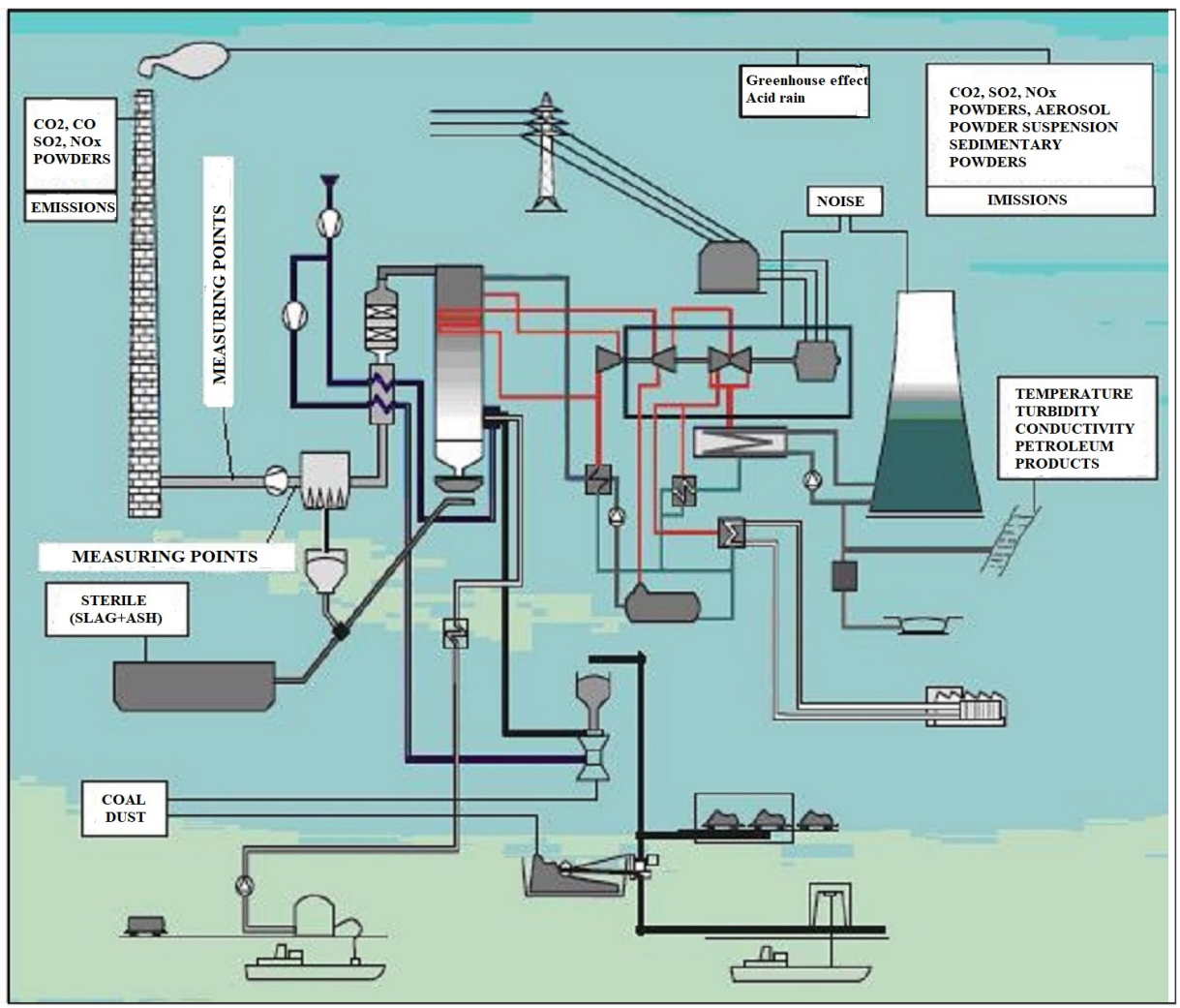

Fig. 1. Flow-chart of the technological process and sampling points.

The measurements included monitoring of the flux of combustion gasses and of pollutant in the flue gas (Figure 1)

The discharge rate of the flue gas depends on fuel type, power rating of the plant and combustion method [2]. The temperature of the flue gas is influenced by Sulphur content of the fuel and can reach $170 \div 180{ }^{\circ} \mathrm{C}$ in order to prevent acid precipitation.

The flux of pollutants includes harmful substances (ash, compounds of Nitrogen and Oxygen, $\mathrm{NO}_{x}$; compounds of Sulphur and Oxygen, $\mathrm{SO}_{x}$; hydrochloric acid, $\mathrm{HCl}$; uncombusted hydrocarbons, $\mathrm{HC}$, etc.) which are discharged into the atmosphere together with the flue gas. It depends on improvements of systems that remove the harmful substances and is limited by strict environmental protection norms. Effective dispersion is necessary to limit the level of pollution at ground level and requires very tall flues, up to $300 \div 400 \mathrm{~m}$ in height. This flux, together with the atmospheric protection constraints determines the selection of flue location $[3,4]$.

This paper presents a comparative analysis of the greenhouse gases and particulate materials for two power generator units (nr. 5 and $\mathrm{nr}$. 2) from the same power station. 
Comparative graphs were prepared using the results obtained through experimental measurements. The results were compared with data from the technical literature and solutions to reduce the values measured "in situ" were developed.

The measurement values were converted in appropriate units of measure to allow for a comparative analysis of the obtained data as well as an analysis complying with the current legislation.

\section{Experimental measurements}

The measurements were made using the following measurement devices: an anemometer with cups, an Asman Psychrometer, a recording thermometer type ULTRACUSTTermophil 4444, a Voltcraft 4-in-1 multi-meter, a portable isokinetic sampler type IsoStack Basic HV, an infrared thermal camera type 2D Thermo HiTester 3460-50 and a gas analyser type Testo 350 .

Experimental measurements were taken from locations situated at the outlets of the electrostatic filters as well as from the access points located after the combustion gas discharge fans (Figure 1). The measurements included the mass flow rate $(\mathrm{t} / \mathrm{h})$ and concentrations (\%, p.p.m., $\mathrm{mg} / \mathrm{m}^{3} \mathrm{~N}$ ) for the following indicators: $\mathrm{O}_{2}, \mathrm{CO}, \mathrm{CO}_{2}, \mathrm{NOx}, \mathrm{SO}_{2}$, and particulates such as: PM 10, PM 2,5, as well as total emissions (Table 1)

Table 1. Concentrations of pollutants measured experimentally.

\begin{tabular}{|c|c|c|c|c|c|c|c|c|}
\hline $\begin{array}{c}\text { Energy } \\
\text { Group } \\
/ \\
\text { Exhaust } \\
\text { circuit }\end{array}$ & $\underset{\mathrm{mg} / \mathrm{m}^{3} \mathrm{~N}}{\mathrm{CO}}$ & $\underset{\mathrm{mg} / \mathrm{m}^{3}{ }^{3}}{\mathrm{NO}_{\mathrm{N}}}$ & $\begin{array}{c}\mathrm{CO}_{2} \\
\mathrm{~g} / \mathrm{m}^{3} \mathrm{~N}\end{array}$ & $\underset{\mathrm{mg} / \mathrm{m}^{3} \mathrm{~N}}{\mathrm{SO}_{2}}$ & $\begin{array}{l}\text { Powders } \\
\mathrm{mg} / \mathrm{m}^{3} \mathrm{~N}\end{array}$ & $\begin{array}{l}\text { PM 2,5 } \\
\mathrm{mg} / \mathrm{m}^{3} \mathrm{~N}\end{array}$ & $\begin{array}{l}\text { PM 10 } \\
\mathrm{mg} / \mathrm{m}^{3} \mathrm{~N}\end{array}$ & $\begin{array}{c}\text { Coarse } \\
\text { particles } \\
\text { with } 10 \\
\mu \mathrm{m}<\mathrm{D}< \\
45 \mu \mathrm{m} \\
\mathrm{mg} / \mathrm{m}^{3} \mathrm{~N}\end{array}$ \\
\hline 5/A & 4.018 & 485.23 & 132.8 & 2641 & 235.19 & 10.73 & 32.05 & 85.52 \\
\hline $5 / \mathrm{A}$ & 5.324 & 642.837 & 112.5 & 2637 & 215.63 & 9.84 & 29.39 & 78.4 \\
\hline $5 / \mathrm{A}$ & 2.695 & 701.959 & 149.7 & 3844 & 187.49 & 8.56 & 25.55 & 68.17 \\
\hline $5 / \mathrm{A}$ & 3.987 & 623.261 & 108.4 & 2570 & 218.67 & 9.97 & 29.8 & 79.51 \\
\hline $5 / \mathrm{B}$ & 4.043 & 615.934 & 157.2 & 2554 & 220.52 & 10.05 & 30.05 & 80.19 \\
\hline 5/B & 5.36 & 674.058 & 136.2 & 2652 & 204.17 & 9.31 & 27.83 & 74.24 \\
\hline $5 / \mathrm{B}$ & 6.728 & 637.822 & 148.2 & 3725 & 198.13 & 9.03 & 27.01 & 72.04 \\
\hline $5 / \mathrm{B}$ & 6.702 & 562.946 & 139.4 & 2663 & 224.71 & 10.25 & 30.63 & 81.7 \\
\hline $2 / \mathrm{B}$ & 4.062 & 268.116 & 165.2 & 1870 & 202.64 & 9.24 & 27.62 & 73.68 \\
\hline $2 / \mathrm{A}$ & 4.05 & 279.477 & 157.8 & 1697 & 221.18 & 10.08 & 30.15 & 80.42 \\
\hline
\end{tabular}

The values of the experimental measurements were adjusted as functions of the atmospheric conditions (atmospheric pressure, temperature and relative humidity).

The mass flow rates of the pollutants were determined using the hourly mass flow rates of combustion gases averaged annually.

Table 1 summarises the average values of the pollutants expressed in $\mathrm{mg} / \mathrm{m}^{3}{ }_{\mathrm{N}}$. The reduction to the standard sate was carried out according to the relationships published in the 
technical literature [5]. Particulates were determined in terms of total quantities and their differentiation was made using statistical data published in the technical literature.

Using the results presented in Table 1 comparative graphs were produced for the emissions from the power generator units presented in Figures 2 to 5.
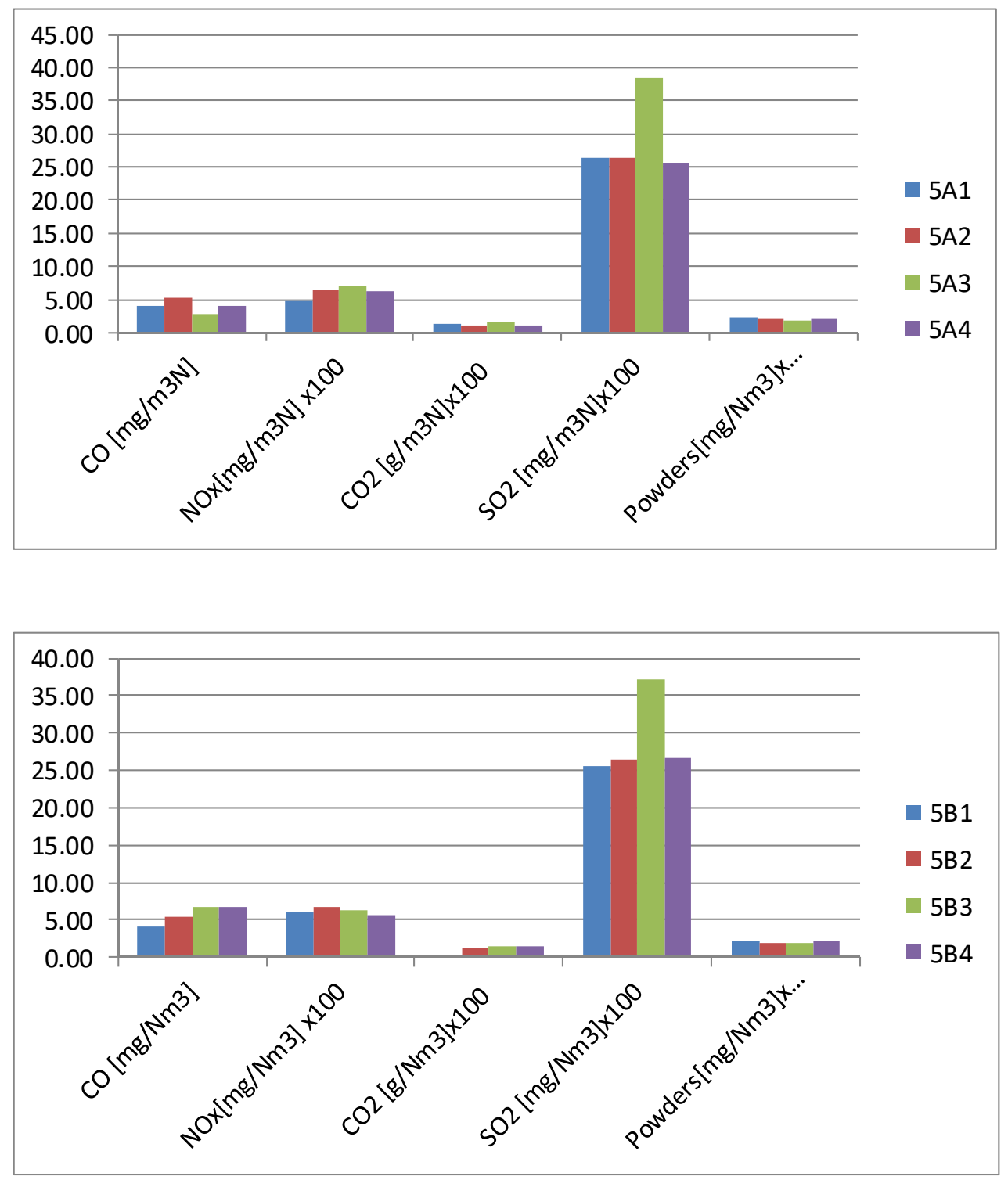

Fig. 2. Energy group 5 - Evacuation A.

Fig. 3. Energy group 5 - Evacuation B. 


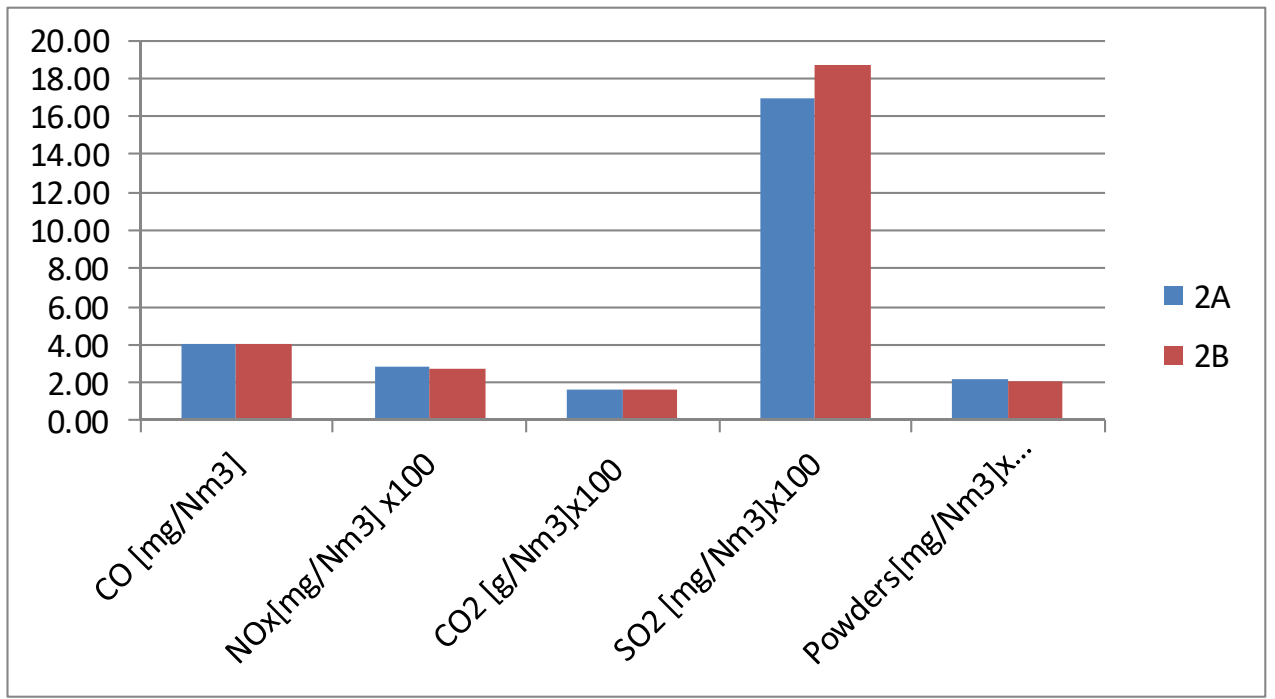

Fig. 4. Energy group 2.

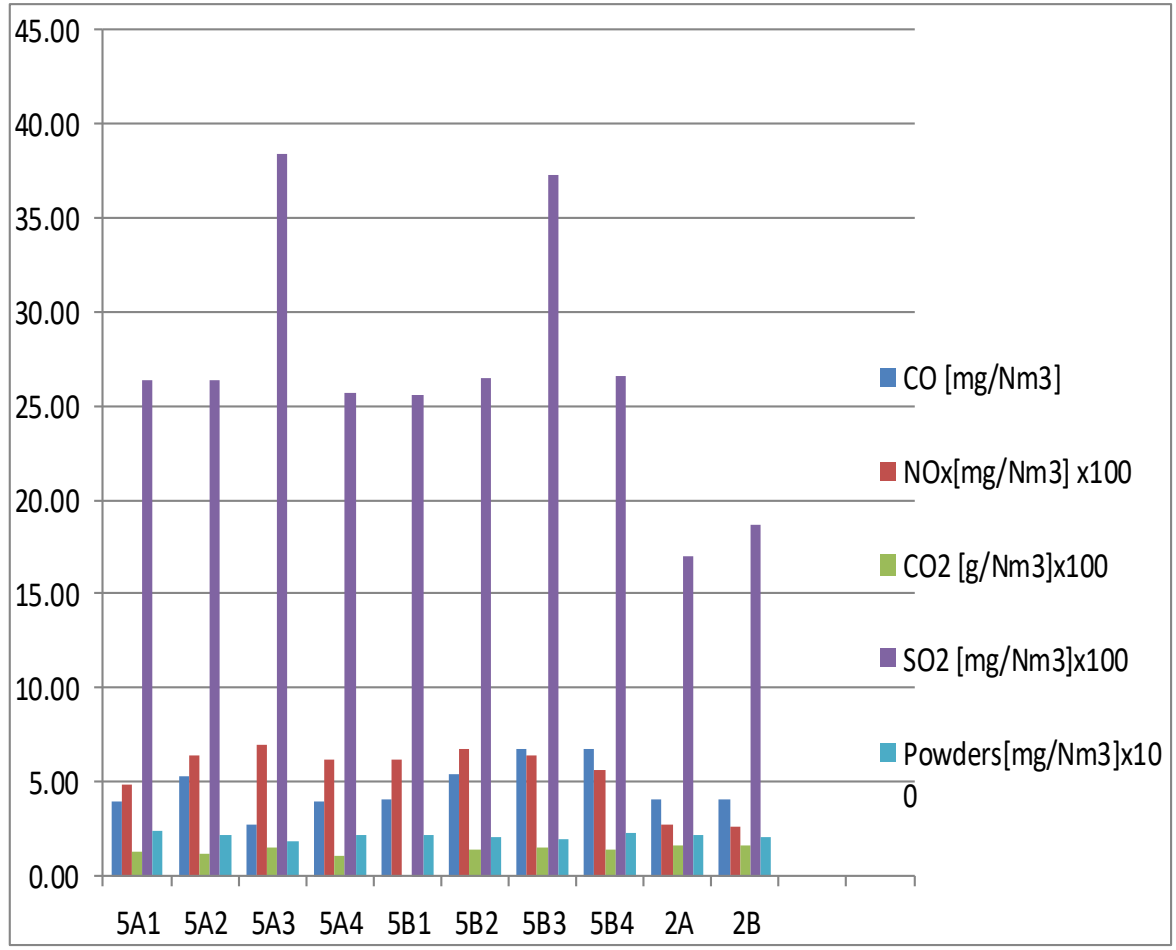

Fig 5. Comparative values of emissions from the power generator units considered.

Table 2 summarises the average values of the mass flow rate $(\mathrm{t} / \mathrm{h})$ of the pollutants calculated using a numerical scheme. Using the values presented in Table 2 a series of comparative graphs were produced for the emissions from the power generator units considered which are presented in Figures 6 to 9. 
Table 2. Mass based values of polluting emissions determined experimentally.

\begin{tabular}{|c|c|c|c|c|c|c|c|c|}
\hline $\begin{array}{c}\text { Energy } \\
\text { Group } \\
/ \\
\text { Exhaus } \\
\text { t circuit }\end{array}$ & $\begin{array}{c}C O \\
t / h\end{array}$ & $\begin{array}{c}N_{x} \\
t / h\end{array}$ & $\begin{array}{c}\mathrm{CO}_{2} \\
\mathrm{t} / \mathrm{h}\end{array}$ & $\begin{array}{c}\mathrm{SO}_{2} \\
\mathrm{t} / \mathrm{h}\end{array}$ & $\begin{array}{c}\text { Powders } \\
\text { t/h }\end{array}$ & $\begin{array}{c}\text { PM 2,5 } \\
\text { t/h }\end{array}$ & $\begin{array}{c}\text { PM } 10 \\
\text { t/h }\end{array}$ & $\begin{array}{c}\text { Coarse } \\
\text { particle } \\
\text { S with } \\
10 \\
\mu \mathrm{m}<\mathrm{D}< \\
45 \mu \mathrm{m} \\
\mathrm{t} / \mathrm{h}\end{array}$ \\
\hline $5 / \mathrm{A}$ & 0.00217 & 0.317 & 71.871 & 1.429 & 0.12723 & 0.00580 & 0.01734 & 0.04626 \\
\hline $5 / \mathrm{A}$ & 0.00277 & 0.355 & 58.593 & 1.374 & 0.11234 & 0.00512 & 0.01531 & 0.04084 \\
\hline 5/A & 0.00143 & 0.373 & 79.634 & 2.045 & 0.09974 & 0.00454 & 0.01359 & 0.03626 \\
\hline $5 / \mathrm{A}$ & 0.00206 & 0.322 & 65.063 & 1.329 & 0.11305 & 0.00515 & 0.01540 & 0.04110 \\
\hline $5 / \mathrm{B}$ & 0.00219 & 0.334 & 85.333 & 1.387 & 0.11974 & 0.00546 & 0.01632 & 0.04353 \\
\hline $5 / \mathrm{B}$ & 0.00276 & 0.347 & 70.118 & 1.366 & 0.10514 & 0.00479 & 0.01433 & 0.03823 \\
\hline $5 / \mathrm{B}$ & 0.00357 & 0.339 & 78.669 & 1.978 & 0.10520 & 0.00479 & 0.01433 & 0.03825 \\
\hline $5 / \mathrm{B}$ & 0.00348 & 0.293 & 72.486 & 1.385 & 0.11684 & 0.00532 & 0.01592 & 0.04248 \\
\hline $2 / \mathrm{B}$ & 0.00210 & 0.139 & 85.74 & 0.971 & 0.10517 & 0.00479 & 0.01433 & 0.03823 \\
\hline $2 \mathrm{~A}$ & 0.00213 & 0.148 & 83.334 & 0.896 & 0.11678 & 0.00532 & 0.01591 & 0.04246 \\
\hline
\end{tabular}

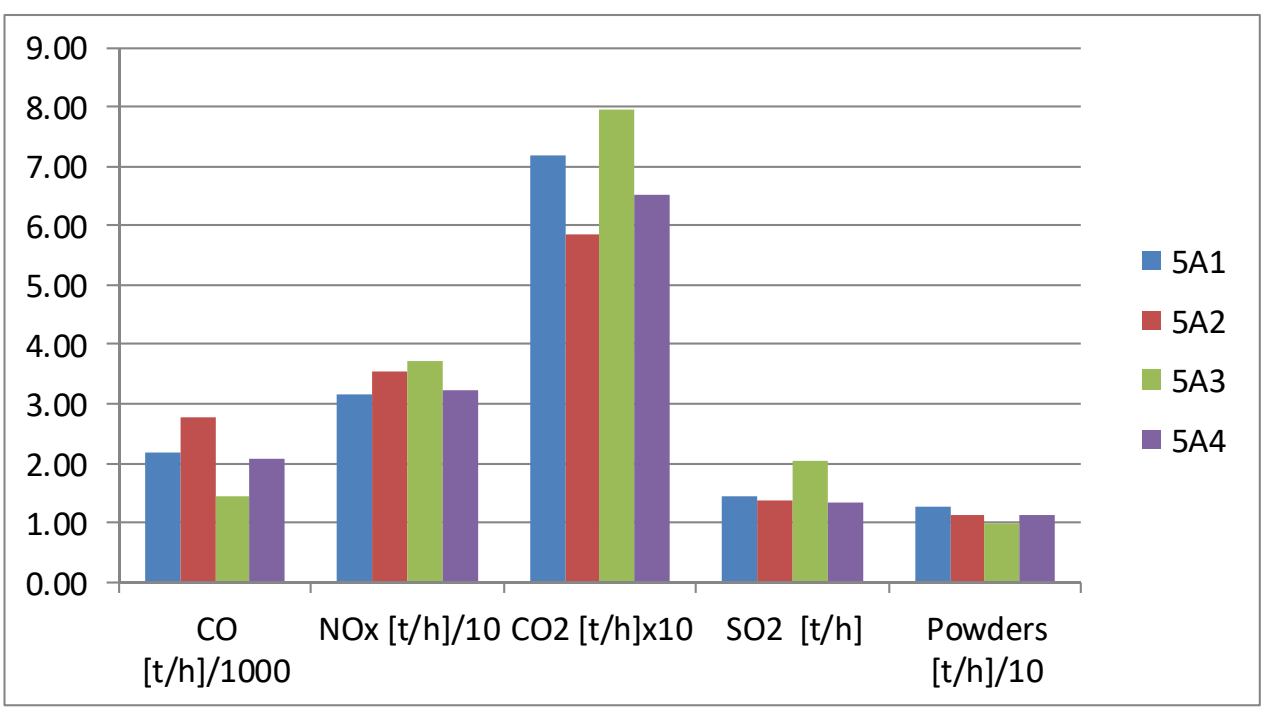

Fig. 6. Energy group 5 - Evacuation A - the mass flow rate $(\mathrm{t} / \mathrm{h})$ of the pollutants. 


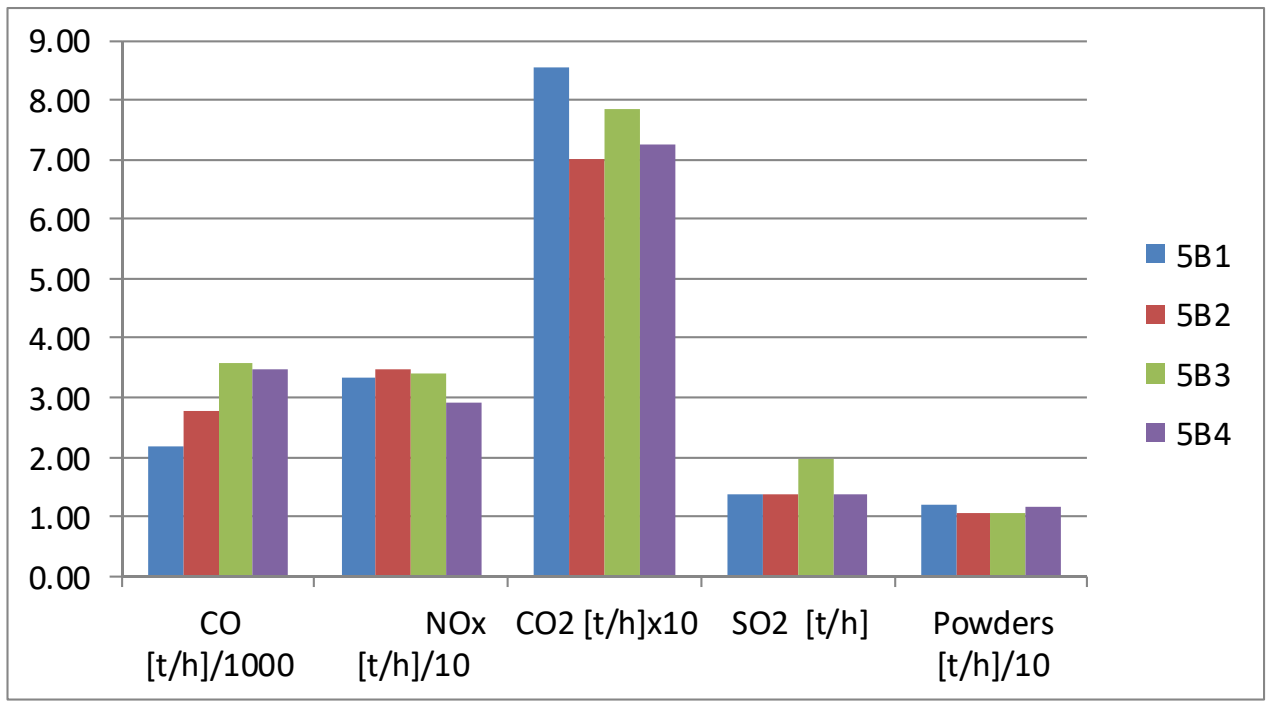

Fig. 7. Energy group 5 - Evacuation $B$ - the mass flow rate $(t / h)$ of the pollutants.

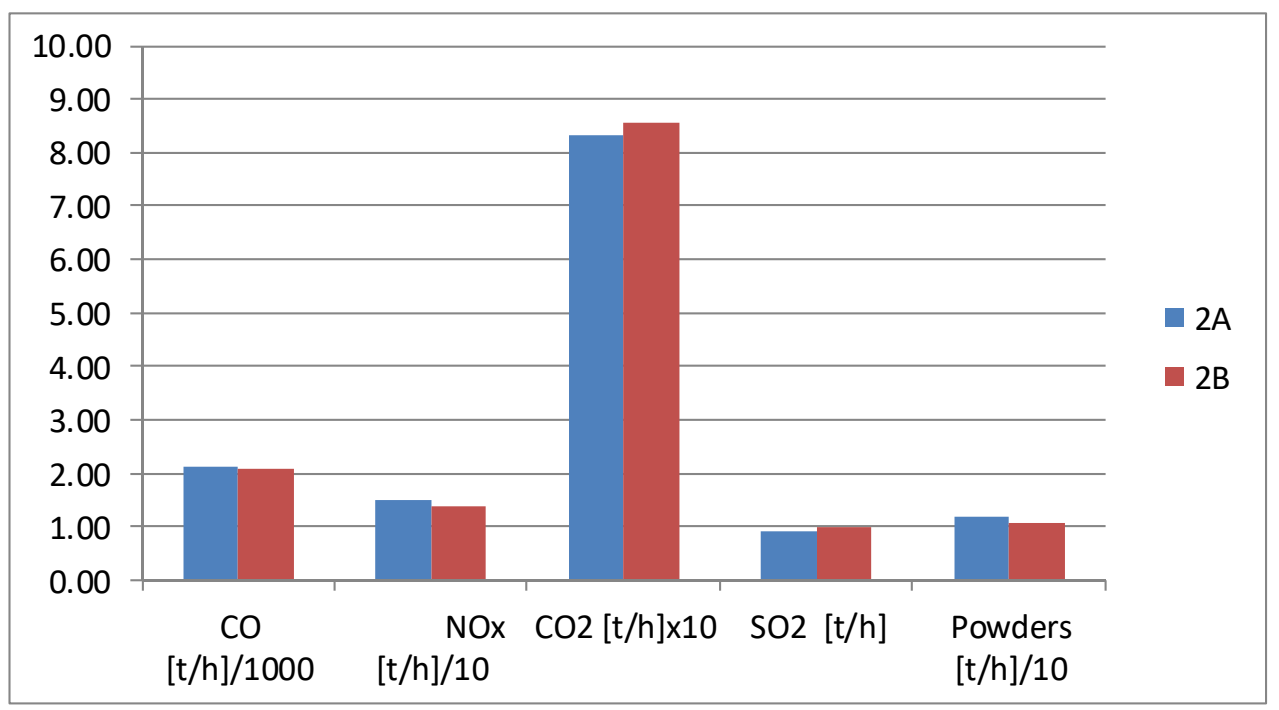

Fig. 8. Energy group 2 - the mass flow rate $(\mathrm{t} / \mathrm{h})$ of the pollutants. 


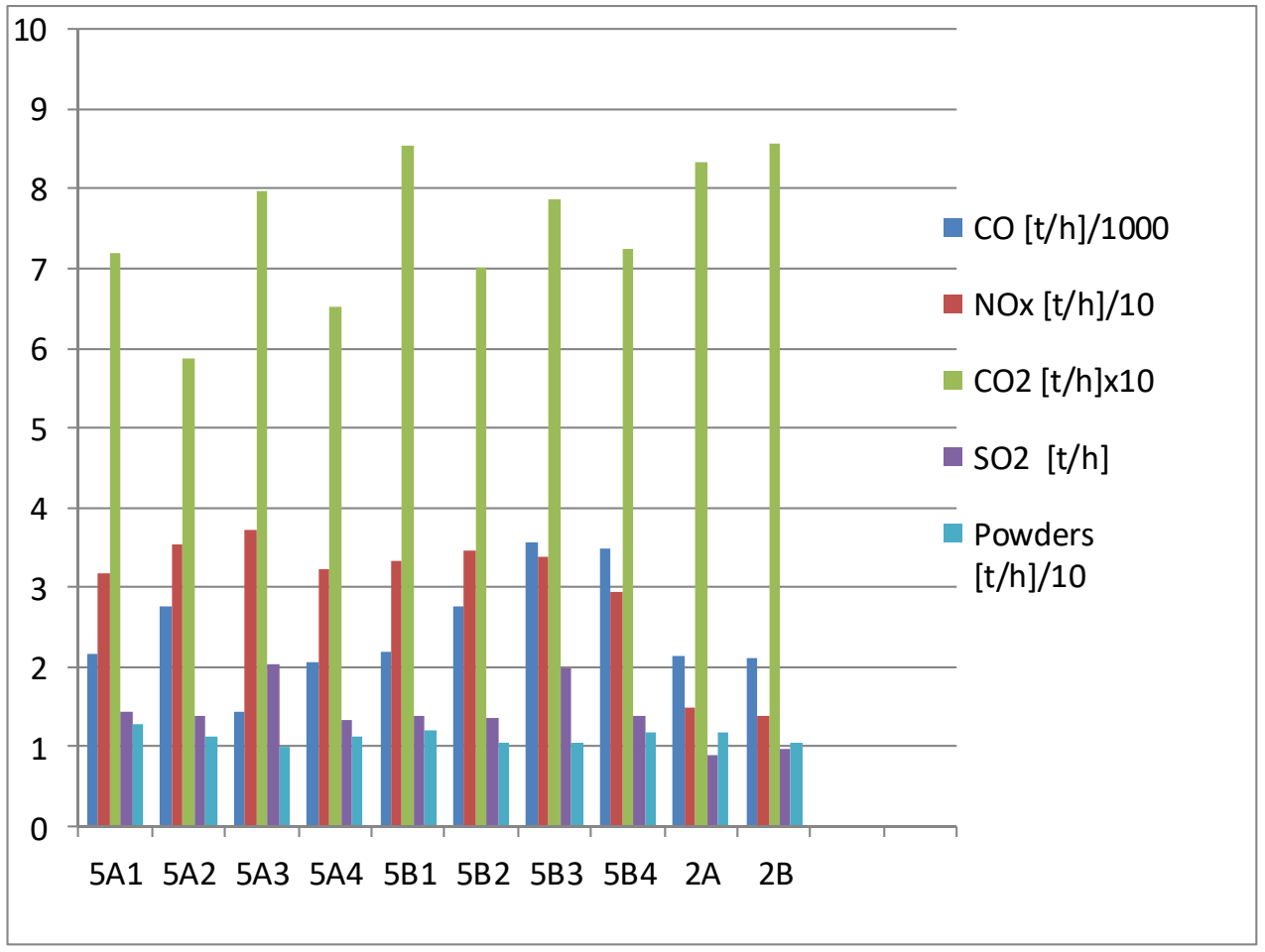

Fig 9. Comparative values of emissions from the power generator units considered - the mass flow rate $(\mathrm{t} / \mathrm{h})$ of the pollutants.

\section{Conclusions}

The current paper is important in the context of the efforts of energy producers in terms of complying with the current legislation as well as for reducing greenhouse gas and particulate pollution. The values determined from "in situ" studies show that the legal limits were significantly exceeded [6]. So: $\mathrm{SO}_{2}$ emissions $\left(\mathrm{mg} / \mathrm{m}^{3} \mathrm{~N}\right)$ exceeds 6 to 15 times the legal limits; $\mathrm{NO}_{\mathrm{x}}$ emissions $\left(\mathrm{mg} / \mathrm{m}^{3} \mathrm{~N}\right)$ exceeds 3.5 times the maximum legal limits; particulate emissions $\left(\mathrm{mg} / \mathrm{m}^{3}\right.$ ) exceeding 7 to 9 times the legal limits.

Their reduction may be possible by a more careful control of the combustion process and using fuel mixtures compositions according to the specifications of the burner manufacturers.

The possible solutions are: installing a desulphurization and dense sludge facility, special installations for $\mathrm{NO}_{\mathrm{x}}, 4$ field electrical filters with up to date maintenance.

\section{References}

1. Raport de mediu pentru strategia energetică a României 2020-2030, cu perspectiva anului 2050 Ministerul Energiei (2020)

2. D. Borsan, Fizica atmosferei şi poluarea aerului (Editura Univ. Bucureşti, 1998)

3. I. Ionel, Dispersia noxelor (Editura Univ. "Politehnica" Timişoara, 1998)

4. I. Ionel, C. Ungureanu, Termoenrgetica şi mediul (Editura Tehnică, Bucureşti, 1996)

5. V. Rojanschi, Ghidul evaluatorului şi auditorului de mediu (Editura economică Bucureşti, 2008)

6. Directive 2001/81/CE (2001) 